\title{
PENINGKATAN RAGAM GENETIK ANGGREK Dendrobium spp MELAUI HIBRIDISASI UNTUK MENDUKUNG PERKEMBANGAN ANGGREK DI INDONESIA
}

\author{
Sri Hartati $^{1 *}$, Agus Budiyono ${ }^{2}$ dan Ongko Cahyono ${ }^{2}$ \\ ${ }^{1}$ Fakultas Pertanian, Universitas Tunas Pembangunan Surakarta \\ ${ }^{2}$ Fakultas Pertanian, Universitas Sebelas Maret Surakarta \\ Contact Author : tatik_oc@yahoo.com
}

\begin{abstract}
ABSTRAK
Perbaikan genetik melalui persilangan interspesifik antara tetua terpilih anggrek Dendrobium spp diarahkan untuk meningkatkan mutu genetik dan nilai ekonomi anggrek alam dipasaran. Anggrek Dendrobium adalah salah satu genus anggrek yang banyak diminati. Upaya peningkatan mutu genetik anggrek memiliki kendala pada teknik penyilangan dan perbanyakan biji hasil hibridisasi/persilangan. Penelitian bertujuan untuk: (1) mendapatkan teknik penyilangan yang dapat menghasilkan biji dengan tingkat fertilitas tinggi dan (2) mendapatkan anggrek hibrida baru yang memiliki keunggulankeunggulan karakter. Penelitian dilakukan di Pusat Konservasi Tumbuhan Kebon Raya LIPI Bogor. Persilangan dilakukan pada 4 sampai 6 individu yang berbunga. Persilangan dilakukan dengan cara menyilangkan tetua terpilih sebagai tetua jantan atau betina Pollinia ditransfer dari anther ke stigma dengan menggunakan tusuk gigi steril, dengan metode (i) crossing , (ii) Resiprocal.Pengamatan dilakukan terhadap karakter induk yang digunakan, waktu persilangan sampai dengan panen buah, dan lama berkecambah. Dari penelitian dihasilkan 4 seri silangan secara resiprok sampai perkecambahan yaitu q Dendrobium mirbelianum $x$ o Dendrobium liniale, + Dendrobium liniale $x$ ते Dendrobium mirbelianum, $q$ Dendrobium liniale $x$ Dendrobium bigibbum, $q$ Dendrobium bigibbum $x$ त Dendrobium liniale. Persentase keberhasilan semua persilangan dan resiproknya adalah $100 \%$ kecuali persilangan $q$ D.lineale $x \delta^{1} D$. tobaense dan resiproknya tingkat keberhasilannya 0\%. Waktu terbentuk buah 3-9 hari, masaknya biji bervariasi antara 81-123 hari dan lama terbentuk protokorm bervariasi 1536 hari.
\end{abstract}

Keywords: anggrek, Dendrobium, hibrida, hibridisasi

\section{PENDAHULUAN}

Vanda sebagai tanaman hias umumnya telah dimanfaatkan sebagai penghasil tanaman hias dan bunga potong. Keanekaragaman warna bunga dengan berbagai variasinya, menyebabkan Vanda tidak pernah surut dari penggemarnya Variasi yang ada pada anggrek merupakan salah satu keunggulan tanaman tersebut yang memungkinkan untuk dibuat hibridahibrida baru.
Keunggulan tanaman anggrek ditentukan oleh warna, ukuran, bentuk, susunan, jumlah kuntum bunga pertangkai, panjang tangkai dan daya tahan kesegaran bunga (Widiastoeti et al., 2010)

Usaha peningkatan anggrek secara kualitas dapat dilakukan dengan usaha perbaikan genetik melalui persilangan, sedangkan untuk peningkatan kuantitas dapat dilakukan dengan perbanyakan melalui kultur in vitro, jumlah anakan yang didapat lebih banyak dalam waktu 
yang relatif lebih singkat. Oleh karena itu pemuliaan anggrek diupayakan untuk memperluas keragaman genetik pada bentuk dan warna yang unik, disenangi konsumen, frekuensi berbunga tinggi dan tahan terhadap patogen penyebab penyakit serta cekaman lingkungan

Pada tanaman anggrek persilangan ditujukan untuk mendapatkan varietas baru dengan warna dan bentuk yang menarik, mahkota bunga kompak dan bertekstur tebal sehingga dapat tahan lama sebagai bunga potong, jumlah kuntum banyak dan tidak ada kuntum bunga yang gugur dini akibat kelainan genetis serta produksi bunga tinggi (Hadi, 2005).

Penelitian ini diharapkan bukan saja akan dapat memperbaiki teknik persilangan pada tanaman anggrek namun juga akan dapat menghasilkan anggrek hibrida baru hasil persilangan interspesifik anggrek Vanda celebica, Vanda tricolor ,Vanda dearei, dan Vanda insignis.

\section{METODE PENELITIAN}

1. Bahan dan Alat

Tanaman anggrek Dendrobium liniale (Sulawesi), Dendrobium mirbelianum (Papua), Dendrobium tobaense (Maluku), Dendrobium bigibbum (Maluku) Dendrobium anosmum (Papua),

2. Tempat penelitian dilakukan di Pusat Konservasi Tumbuhan Kebon Raya LIPI Bogor

3. Pelaksanaan Penelitian

Persilangan dilakukan pada pagi hari $\mathrm{j}$. 07.00 - 08.00 dengan menyilangkan tetua terpilih sebagai tetua jantan atau betina, persilangan dilakukan secara interspesifik maupun resiproknya
4. Rancangan Penelitian

Merupakan percobaan lapangan , meliputi dua percobaan persilangan

a. Persilangan interspesies :

1) $q D$. liniale $\mathrm{x} \curvearrowright D$. mirbelianum

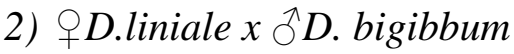

3) + $D$. liniale $x \stackrel{\wedge}{\top} D$. tobaense

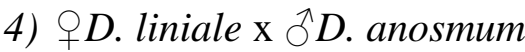

b. Persilangan resiprok:

1) + D.mirbekianum $x \curvearrowright D$. liniale

2) $\bigcirc D$. bigibbum $x \curvearrowright D$. liniale

3) $q D$. tobaense $\mathrm{x}$ o $D$. liniale

4) D. anosmum $x \stackrel{\uparrow}{\top} D$. liniale

5. Pengamatan : Persentase keberhasilan persilangan, Umur masak, terbentuk protokorm

\section{HASIL DAN PEMBAHASAN}

\section{Persentase Keberhasilan persilangan}

Menurut Iswanto

(2005)

persilangan dikatakan berhasil apabila 34 hari setelah persilangan tangkai kuntum bunga induk betina masih segar atau berwarna kehijauan. Beberapa hari kemudian kelopak dan mahkota bunganya layu, kering dan akhirnya rontok, kemudian muncul calon buah yang berbentuk memanjang dan berwarna hijau.

Demikian juga penelitian Sivanaswari et al., 2011, jika persilangan dilakukan kurang dari 1 minggu maka permukaan stigma reseptif terhadap serbuk sari. Setelah 2 minggu, bunga menutup dan serbuk sari menjadi coklat dan reseptif

Dari tabel 1 terlihat bahwa persilangan D.lineale sebagai induk betina maupun sebagai induk jantan menunjukkan keberhasilan 0- 100\%,

Hal ini terlihat bahwa 9 D.lineale $\mathrm{x}$

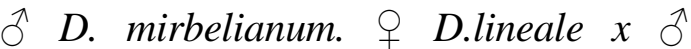
D.bigibbum, $q$ D.lineale $x$ § D.anosmum menunjukkan keberhasilan 100\%, demikian juga secara resiprok 
(kebalikan) Sebaliknya pada persilangan q D.lineale $x \widehat{0} D$. tobaense $0 \%$, dan resiproknya persilangan tidak ada yang berhasil (0\%).

Kegagalan dalam persilangan juga dapat disebabkan belum masaknya alat kelamin jantan (anthera) atau alat kelamin betinanya (stigma) yang belum siap sehingga persarian tidak terjadi (Pudjogunarto, 2001)

Sedang hasil penelitian Aries et al, (2010), bahwa keberhasilan persilangan antara Vanda tricolor dengan Vanda limbata adalah $100 \%$.

Penelitian Hartati

persilangan antara Phalaenopsis $s p$ dan Vanda tricolor bersifat kompatibel, namun untuk menghasilkan biji Phalaenopsis sp sebagai induk jantan dan Vanda tricolor sebagai induk betina berpeluang lebih besar dari pada secara resiprok (kebalikannya).

\section{Saat terbentuk buah}

Hasil penelitian (Tabel 1) menunjukkan bahwa saat terbentuk buah berkisar antara $3-9$ hari setelah dilakukan persilangan. Saat terbentuk buah dihitung mulai saat terjadinya persilangan sampai buah terbentuk yang ditandai dengan adanya pembengkakan pada pangkal buah. Waktu yang dibutuhkan untuk fertilisasi (pembuahan) pada tanaman anggrek sangat bervariasi, tergantung jenisnya, yang dihitung sejak penyerbukan hingga terjadinya pembuahan (Widiastoety, 2003).

Penelitian Hartati (2010) bahwa waktu terbentuk buah pada persilangan antara Vanda tricolor sebagai induk betina dan Phalaenopsis sp induk jantan berkisara 4- 5 hari. Selanjutnya pada persilangan Phalaenopsis Joane Kileup June dan Vanda tricolor pada 3 minggu setelah bunga mekar buah terbentuk 12 hari setelah persilangan.

\section{Waktu masak ( panen) buah}

Dari tabel 2 rata-rata umur masak / panen buah hasil persilangan Dendrobium spp 90-120 hari, secara terperinci persilangan $\bigcirc$ D.lineale $\mathrm{x} \widehat{\sigma}$ D. mirbelianum 90 hari, tetapi secara resiprok pada persilangan $q D$. mirbelianum $x$ ○ D.lineale umur masak / panen buah lebih lama berkisar 114 119 hari.

Hasil penelitian Aries et al, (2010), bahwa waktu masak buah antara Vanda tricolor dengan Vanda limbata adalah 170- 180 hari.

Menurut Widiastoety persilangan sebaiknya dilakukan secara bolak - balik (reciprocal) untuk membandingkan dan mengetahui daya kompatibilitas dan daya fertilitasnya. Daya kompatibilitas adalah persentase kemampuan membentuk buah,

Tabel 1. Rata-rata keberhasilan persilangan, umur panen dan lama kecambah

\begin{tabular}{|c|c|c|c|}
\hline No & Jenis persilangan & $\begin{array}{c}\text { Keberhasilan } \\
\text { persilangan }(\%)\end{array}$ & $\begin{array}{l}\text { Saat terbentuk } \\
\text { buah (hari) }\end{array}$ \\
\hline 1 & q D.lineale x $\widehat{o} D$. mirbelianum & 100 & 5 \\
\hline 2 & † D.lineale $x \widehat{\uparrow}$ D.bigibbum & 100 & 7 \\
\hline 3 & † D.lineale $x \bigcirc^{\widehat{D}}$ D. tobaense & 0 & 0 \\
\hline 4 & 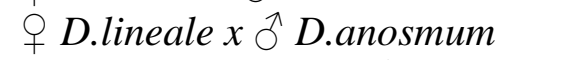 & 100 & 9 \\
\hline 5 & 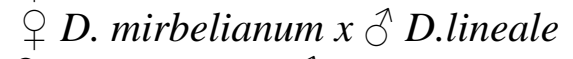 & 100 & 3 \\
\hline 6 & + D.bigibbum $x \lesssim$ D.lineale & 100 & 4 \\
\hline 7 & q D. tobaense $x \circlearrowleft$ D.lineale & 0 & 0 \\
\hline 8 & 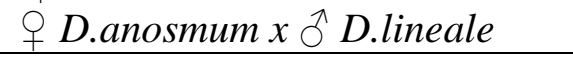 & 100 & 7 \\
\hline
\end{tabular}

Caraka Tani - Jurnal Ilmu-Ilmu Pertanian Volume XXIX No. 2 Oktober 2014 
Tabel 2. Rata-rata umur masak (panen) dan lama kecambah (terbentuk protocorm)

\begin{tabular}{|c|c|c|c|}
\hline No & Jenis persilangan & $\begin{array}{c}\text { Umur masak } \\
\text { (hari) }\end{array}$ & $\begin{array}{l}\text { Lama Kecambah/ ter- } \\
\text { bentuk protocorm (hari) }\end{array}$ \\
\hline 1 & † D.lineale x $\widehat{\AA}$ D. mirbelianum & 90 & 16 \\
\hline 2 & ○ D.lineale $x$ ठิ D.bigibbum & 120 & 26 \\
\hline 3 & ㅇ D.lineale $x{ }^{\widehat{\lambda}}$ D. tobaense & - & - \\
\hline 4 & 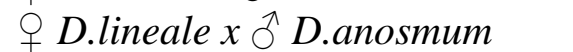 & gugur & - \\
\hline 5 & † D. mirbelianum $x$ § D.lineale & 114 & 25 \\
\hline 6 & + D.bigibbum $x \overbrace{}^{\lambda}$ D.lineale & 119 & 25 \\
\hline 7 & O D. tobaense $x \circlearrowleft$ D.lineale & - & - \\
\hline 8 & O D.anosmum $x$ ô D.lineale & gugur & - \\
\hline
\end{tabular}

sedangkan daya fertilitas adalah kemampuan terjadinya fertilisasi (pembuahan)

\section{Lama berkecambah (terbentuknya protocorm)}

Dari hasil penelitian (Tabel 2) menunjukkan rata-rata lama perkecambahan hasil persilangan Dendobium spp adalah 16 - 26 hari.

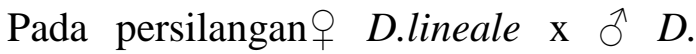
mirbelianum 16 hari, tetapi secara resiprok pada persilangan ${ }_{+} D$. mirbelianum $x \quad$ ${ }^{\wedge}$ D.lineale 25 hari. Perkecambahan biji anggrek Vanda tricolor mengalami hambatan, diduga karena tingginya kadar fenolik dari biji yang bersifat toksik sehingga menghambat pertumbuhan dan perkembangangan embrio.

Dijelaskan pada penelitian Dwiyanti et al (2009), penambahan ekstrak tomat pada media kultur dapat mempercepat perkecambahan, menginduksi protokorm berwarna dan dapat menekan kematian embrio/protokorm anggrek Vanda tricolorLindl. selama periode perkembangannya.

\section{KESIMPULAN}

1. Persentase Keberhasilan semua persilangan dan resiproknya adalah 100\% kecuali persilangan $\circ$ D.lineale $x$ ऽ $D$. tobaense dan resiproknya tingkat keberhasilannya $0 \%$

2. Saat terbentuk buah D.lineale sebagai induk betina berkisar 5-9 hari, tetapi secara resiprok pada persilangan D.lineale sebagai induk jantan saat terbentuk buah 3-9 hari

3. Umur masak pada persilangan D.lineale sebagai induk betina berkisar 90 - 120 hari, tetapi secara resiprok pada persilangan D.lineale sebagai induk jantan umur masak buah 114- 115 hari.

4. Terbentuk protocorm (lama berkecambah ) D.lineale sebagai induk betina berkisar $16-26$ hari, tetapi secara resiprok pada persilangan D.lineale sebagai induk jantan 18-23 hari

\section{SARAN}

Sebaiknya tidak semua bunga pada satu tanaman dilakukan persilangan 


\section{DAFTAR PUSTAKA}

Aries Bagus Sasongko, Ari Indrianto dan Endang Semiarti, 2010. Identifikasi Genotip Hibrida hasil persilangan anggrek local Vanda tricolor Lindl var suavis asal Merapi dan Vanda Limbata Blume dengan PCR-RFLP pada daerah intergenerik trnL-F DNA Kloroplas. Seminar Nasional Biologi. Bidang Keaneka ragaman hayati.

Dwiyani R, Azis Purwantoro, Ari Indrianto, dan Endang Semiarti. 2009. Peningkatan kecepatan pertumbuhan embrio anggrek Vanda tricolor Lindl. pada medium diperkaya dengan ekstrak tomat. Prosiding Bioteknologi. ISBN 978602-95471-0-8

Hadi. 2005. Budidaya Tanaman Anggrek. Dalam http://www.deptan.go.id/ditlinhorti . Diakses pada tanggal 18 Februari 2008.

Hartati. 2010. The intergeneric crossing of Phalaenopsis sp. and Vanda tricolor. Jurnal of Biotechnologi and Biodiversity. Vol.1-Number 1 April 2010. ISSN 2087-0183
Iswanto, H. 2005. Merawat dan Membungakan Anggrek Phalaenopsis. AgroMedia Pustaka. Jakarta

Pudjogunarto, W. S. 2001. Studi Penyerbukan Pada Dua Phase Pemasakan Bunga Betina dengan Campuran Tepung Sari-Tepung Tapioka terhadap Hasil Salak Lawu Salacca edulis Reinw. Agrosains. 3(1) : 12-18.

Sivanaswari, Chalaparmal, Thohirah, LA , Fadelah, AA, dan Abdullah, NAP. 2011. Hybridization of several Aerides species and in vitro germination of its hybrid. African Journal of Biotecnology Vol.10 (53),pp.10864-10870.

Widiastoety, D. 2003. Menghasilkan Anggrek Silangan. Penebar Swadaya. Jakarta.

Widiastoety,D; Nina solvia, Muchdar Soaedarjo. 2010. Potensi Anggrek Dendrobium dalam meningkatkan variasi dan Kualitas Anggrek Bunga Potong. Jurnal Litbang Pertanian 29 (3), $2010: 101-106$ 